\title{
Rotational Diversity Effects in a Triticale-based Cropping System*
}

\author{
B.L. Béres ${ }^{1 * *}$, N.Z. Lupwayi ${ }^{1}$, F.J. LARney ${ }^{1}$, B. Ellert ${ }^{1}$, E.G. SMith ${ }^{1}$, T.K. Turkington ${ }^{2}$, \\ D. PAGEAU ${ }^{3}, K$. SEMAGN ${ }^{4}$ and Z. WAng ${ }^{1}$ \\ ${ }^{1}$ Agriculture and Agri-Food Canada, Lethbridge Research Centre, \\ $54031^{\text {st }}$ Avenue South, Lethbridge, Alberta, Canada, T1J 4B1 \\ ${ }^{2}$ Alberta Agriculture, Field Crop Development Centre, $503050^{\text {th }}$ Street, Lacombe, Alberta, Canada, T4L 1W8 \\ ${ }^{3}$ Agriculture and Agri-Food Canada, Research Farm, \\ 1468 Saint-Cyrille St., Normandin, Quebec, Canada, G8M 4K3 \\ ${ }^{4}$ University of Alberta, Department of Agricultural, Food and Nutritional Science, \\ 4-10 Agriculture-Forestry Centre, Edmonton, Alberta, Canada, T6G 2P5 \\ (Received 29 November 2017; Accepted 9 May 2018; \\ Communicated by L. Bona)
}

\begin{abstract}
Research indicates that not all crops respond similarly to cropping diversity and the response of triticale $(\times$ Triticosecale $\mathrm{ssp}$.) has not been documented. We investigated the effects of rotational diversity on cereals in cropping sequences with canola (Brassica napus L.), field pea (Pisum sativum L.), or an intercrop (triticale:field pea). Six crop rotations were established consisting of two, 2-yr low diversity rotations (LDR) (continuous triticale (T-T_LDR) and triticale-wheat (Triticum aestivum L.) (T-W_LDR)); three, 2-yr moderate diversity rotations (MDR) (triticale-field pea (T-P_MDR), triticale-canola (T-C_MDR), and a triticale: field pea intercrop (T- in P_MDR)); and one, 3-yr high diversity rotation (HDR) (canola-triticale-field pea (C-T-P_HDR)). The study was established in Lethbridge, Alberta (irrigated and rainfed); Swift Current (rainfed) and Canora (rainfed), Saskatchewan, Canada; and carried out from 2008 to 2014. Triticale grain yield for the 3-yr HDR was superior over the LDR rotations and the MDR triticale-field pea system; however, results were similar for triticale-canola, and removal of canola from the system caused a yield drag in triticale. Triticale biomass was superior for the 3-yr HDR. Moreover, along with improved triticale grain yield, the 3-yr HDR provided greater yield stability across environments. High rotational diversity (C-T-P_HDR) resulted in the highest soil microbial community and soil carbon concentration, whereas continuous triticale provided the lowest. Net economic returns were also superior for C-T-P_HDR $\left(\$ 670 \mathrm{ha}^{-1}\right)$ and the lowest for T-W_LDR (\$458 $\left.\mathrm{ha}^{-1}\right)$. Overall, triticale responded positively to increased rotational diversity and displayed greater stability with the inclusion of field pea, leading to improved profitability and sustainability of the system.
\end{abstract}

Keywords: rotational diversity, triticale, pulses, canola, bioethanol production, grain yield, net economic returns

\footnotetext{
*This article was presented on the 9th International Triticale Symposium, May 23-27, 2016, in Szeged, Hungary

**Corresponding author; E-mail: brian.beres@agr.gc.ca
} 


\section{Introduction}

In western Canada, Canada Western Soft White Spring (CWSWS), and Canada Prairie Spring (CPS) wheats are utilized as feedstocks for ethanol production. This provides growers with a dual market, i.e. milling industry or ethanol (Beres et al. 2013b). However, there are societal concerns over using food crops (wheat) for fuel (Karp and Richter 2011). To alleviate concern, alternatives to wheat for ethanol production are being explored. Triticales $(\times$ Triticosecale $)$ are hybrids derived from interspecific crosses between common wheat (Triticum aestivum L.) and rye (Secale cereal L.). Since the first introduction to Canada in the 1960 s, research efforts in winter and spring triticale development has improved agronomic performance and disease resistance for greater adaptation to the Prairie Provinces. Improvements in starch and lower grain protein comparable or superior to wheat makes triticale well-suited for bioethanol production (Beres et al. 2013a; Beres et al. 2013b). In contrast to CPS wheat, triticale has higher potential for use in ethanol production (Beres et al. 2013a). A study investigating the relative performance of three triticale varieties against a range of market classes of wheat in Canada concluded that triticale was superior to both CPS and Canada Western Red Spring (CWRS) wheats, and similar to CWSWS wheat in many of the agronomic traits desired by ethanol fermentation plants (Beres et al. 2013b). In regions where CWSWS wheat supply is not readily available, triticale varieties can be used as feedstock to improve the consistency of feedstock supply for ethanol production (Beres et al. 2013a).

Although Canadian prairie cropping systems have evolved beyond continuous wheat or wheat-fallow, rotations of only wheat and canola (Brassica napus L.) are common, which not only lacks diversity, but may also result in herbicide resistant weeds, greater incidence of disease, and soil degradation (Kirschenmann 2002). One study (Blackshaw et al. 2001) reported that a continuous winter wheat rotation had greater weed densities than winter wheat-spring canola, winter wheat-lentil (Lens culinaris L.)/flax (Linum usitatissimum L.) and winter wheat-fallow rotations. Another report (Sumner et al. 1981) observed an increase in foliar diseases under a wheat monoculture system. Continuous monoculture cropping systems, excessive cultivation for seedbed preparation, and pest control can also lead to serious erosion of topsoil (Doran 2002). Conversely, multi-year and multi-crop rotations may lead to higher grain yield for each crop, lower pest pressure, less reliance on chemical pesticides, enhanced soil health and increased economic returns (Davis et al. 2012; Gan et al. 2015). For example, numerous studies have reported the benefits of growing pulse and oilseed crops with wheat and barley (Hordeum vulgare L.) (Cutforth et al. 2013; Gan et al. 2015; Williams et al. 2014), but the rotational benefits and economic returns of growing pulses and oilseed crops in a triticale-based cropping system are not well documented. The objective of this study was to determine the effect of rotational diversity on triticale when sequenced with canola field pea (Pisum sativum L.) and soft white spring wheat. 


\section{Materials and Methods}

\section{Field evaluation}

The study consisted of three levels of rotational diversity (low, medium, and high) that involved one spring triticale (cv. AC Ultima) (McLeod et al. 2001), one CWSWS wheat (hereafter referred to as wheat) (cv. Bhishaj) (Randhawa et al. 2012), one spring canola (cv. InVigor5020) and two field pea varieties (cv. CDC Meadow and CDC Golden) (Warkentin et al. 2004; Warkentin et al. 2007). Two, low diversity rotations (LDR) included continuous triticale (T-T_LDR) and triticale-wheat (T-W_LDR) (Table S1*). Three moderate diverse 2-yr rotations (MDR) included triticale-field pea (T-P_MDR), triticale-canola (T-C_MDR), and a triticale-intercrop rotation, which was a 1:1 blend of triticale: field pea (T-inP_MDR). One, high diversity rotation (HDR) consisted of canola-triticale-field pea (C-T-P_HDR). The experiments were established at Lethbridge $\left(49^{\circ} 41^{\prime} \mathrm{N}, 112^{\circ} 45^{\prime} \mathrm{W}\right)$, Alberta, Canada, under both rainfed and irrigated moisture regimes from 2008 to 2014, at Canora (rainfed) (51 $\left.37^{\circ} \mathrm{N}, 102^{\circ} 26^{\prime} \mathrm{W}\right)$, Saskatchewan, Canada, in 2008, 2009 and 2011, and Swift Current (rainfed) $\left(50^{\circ} 16^{\prime} \mathrm{N}, 107^{\circ} 44^{\prime}\right.$ W), Saskatchewan, Canada, from 2008 to 2012 (Table S2).

Soil samples from the 0 to $60 \mathrm{~cm}$ depth were taken in the fall for all the sites before the studies were initiated, after the first rotation cycle and then again at the end of the trial. All samples were air-dried at room temperature, ground on a roller-mill and passed through a 2-mm sieve for soil organic carbon and total nitrogen concentration (further ground to $<0.15 \mathrm{~mm}$ ) determinations. Soil organic carbon and total nitrogen concentration were determined using an elemental analyzer (CE Instruments, Milan, Italy).

Soil samples for microbial community determination were collected at the flag leaf stage of triticale in July 2008 for all sites, July 2012 for Swift Current site and July 2014 for Lethbridge sites. Plants were excavated from four random $0.5-\mathrm{m}$ lengths of row. Loose soil was shaken off the roots and the remaining soil that had strongly adhered to the roots was carefully brushed off and kept as rhizosphere soil. The four samples from each plot were combined, passed through a $2-\mathrm{mm}$ sieve and frozen at $-20{ }^{\circ} \mathrm{C}$ until analysis. Soil microbial community was measured using the substrate-induced respiration method, in which $300 \mathrm{mg}$ of glucose was dissolved in 4.5 to $6.0 \mathrm{~mL}$ water and added to $50 \mathrm{~g}$ soil to bring it to $50 \%$ water-holding capacity. The exact amount of water added depended on the pre-determined water content and water-holding capacity of the soil. After stir-mixing, the soil was incubated in a $1 \mathrm{~L}$ jar for $3 \mathrm{~h}$ at $22{ }^{\circ} \mathrm{C}$ and the amount of $\mathrm{CO}_{2}$ that accumulated in the head space was measured using gas chromatography.

A fully-phased randomized complete block design (RCBD) was used to establish the crop rotational phases at each location. Each crop phase was planted in experimental unit dimensions of $117 \mathrm{~m}^{2}(7.40 \times 15.24 \mathrm{~m})$ with four replications. The cereal crops were sown at a rate of 400 seeds $\mathrm{m}^{-2}$, field pea at $100 \mathrm{seeds} \mathrm{m}^{-2}$, canola at 150 seeds $\mathrm{m}^{-2}$; rates for the intercrop components were reduced to $60 \%$ of normal (AC Ultima:CDC Meadow/ CDC Golden), all using a Conserva Pak ${ }^{\mathrm{TM}}$ air drill configured with knife openers spaced

\footnotetext{
*Further details about the Electronic Supplementary Material (ESM) can be found at the end of the article.
} 
$23 \mathrm{~cm}$ apart. Fertilizer amendments were based on soil test recommendations for each site-year (location $\times$ year combinations) to achieve optimum crop yield. Pest and weed control were managed as described in previous studies (Beres et al. 2013a; Beres et al. $2013 \mathrm{~b})$. The number of heads per plant and per unit area $\left(\mathrm{m}^{2}\right)$, kernel weight, grain test weight, grain yield, grain protein concentration, and biomass were evaluated for triticale in all crop rotations. Determination of crop biomass was measured from four triticale samples per plot collected at physiological maturity from 4 pre-marked areas $\left(0.5 \mathrm{~m}^{2}\right.$ each). The above-ground portion of triticale plants were cut from the marked areas and weighed for wet and dry weight. Triticale biomass was calculated based on the dry weight. Populations of both broad-leaf and grassy weeds were determined from two selected rows, each $1 \mathrm{~m}$ long, 5-6 weeks after seeding. The weed plants were harvested thereafter for further weed biomass determination. The entire plot was harvested with a plot combine equipped with a straight-cut header, pickup reel, and crop lifters. Grain yield per plot was weighed after drying the grains to safe storage moisture content, for example, $13.5 \%$ for cereals, and used to estimate total yield per hectare. A two-kg subsample of grain was used to determine kernel weight (from 250 kernels) and grain test weight $\left(\mathrm{kg} \mathrm{hL}^{-1}\right)$. Whole grain protein concentration was determined from the same subsample using near infrared reflectance spectroscopy technology (Foss Decater GrainSpec, Foss Food Technology Inc., Eden Prairie, MN) (Irvine et al. 2013).

\section{Statistical analyses}

All data were analyzed separately for each crop with the PROC MIXED and GLIMMIX procedures (Littell et al. 2006) of SAS v9.3 (SAS Institute Inc. Cary, USA). Site-years and replicate effects were considered random, whereas rotational diversity effect was considered fixed. Soil nitrogen and carbon data also were analyzed separately for each location with the PROC MIXED and GLIMMIX procedures of SAS v9.3. The replicate effect was considered random, while the year, rotational diversity, and soil depth effects were considered fixed. For all analyses, $\mathrm{LSD}_{0.05}$ was presented with least squares means as a measure of precision and to compare mean difference. A grouping methodology was used to explore system responses and variability (Francis and Kannenberg 1978). The mean and coefficient of variation (CV) were estimated for each rotational diversity. Means were plotted against $\mathrm{CV}$ for each rotational diversity and used to categorize the biplot data into four quadrants/groups, which included high mean grain yield and low variability (optimal, Group I), high mean grain yield and high variability (Group II), low mean grain yield and high variability (poor, Group III), and low mean grain yield and low variability (Group IV).

To explore if rotational diversity is a profitable cropping system strategy, total production costs (variable and fixed costs) for each treatment was estimated based on the operations and inputs used in each year using the 2015 Crop planning guide of Saskatchewan Ministry of Agriculture, Canada (Anonymous 2015). Variable costs include seed, fertilizers, pesticides, machinery fuel and repair costs, custom work and hired labour, utilities and miscellaneous and interest in variable expenses, while fixed costs includes building 
repair, property taxes, business overhead, machinery depreciation, building depreciation, machinery investment, building investment and land investment. The cost and return analyses were calculated for each of the low, medium and high production environments.

\section{Results}

\section{Climatic conditions}

Climatic conditions are summarized in Fig. S1. At the Lethbridge site, the growing season monthly mean temperatures were close to normal from 2008 through 2011. However, both 2012 and 2014 displayed a cooler than normal July and August, and 2013 displayed a cooler August. The growing season monthly mean temperatures at Swift Current were generally higher than with the exception of 2012. Canora experienced growing season monthly mean temperatures higher than normal in 2008 and 2009, near normal in 2010 and 2012, and a cooler July and August in 2011. Lethbridge experienced above average precipitation during the growing seasons in most years other than 2009, which was near normal. There accumulation varied considerably as extreme dry conditions in May were followed by excessively wet conditions in June 2010 and 2014. Similar observations were recorded at Swift Current. Precipitation levels at Canora tended to be lesser than normal in 2008 and 2009 and higher than normal in 2010, 2011 and 2012.

\section{Effects of rotational diversity on crop productivity, yield stability and soil health}

Average grain yield combined across all 22 site-years was highly variable, ranging from 1.68 to $4.62 \mathrm{Mg} \mathrm{ha}^{-1}$ for triticale, 0.68 to $2.35 \mathrm{Mg} \mathrm{ha}^{-1}$ for canola, 1.54 to $3.12 \mathrm{Mg} \mathrm{ha}^{-1}$ for field pea, 1.89 to $3.65 \mathrm{Mg} \mathrm{ha}^{-1}$ for wheat (Table S2; Fig. S2). Overall, triticale produced the highest average grain yield (3.64 $\mathrm{Mg} \mathrm{ha}^{-1}$ ); however, the site-year variability tended to skew the mean triticale grain yield toward a lower than anticipated result (Fig. S2). Among all the four sites, Swift Current produced the least triticale grain yield, whereas the highest average triticale grain yield was recorded for Lethbridge rainfed (Table S2). Lethbridge was the only location where all four crops were evaluated under both rainfed and irrigated conditions. The mean differences between the regimes were modest for all crop phases, which reflected the relatively high rainfall accumulations at Lethbridge, and a hail event at Lethbridge irrigation that depressed overall yield (Fig. S1).

Analysis of variance (ANOVA) indicated important $(\mathrm{P}<0.05)$ responses to rotational diversity for triticale kernel weight, grain protein concentration, grain test weight, grain yield, and biomass (Table S3). Triticale grain yield in both T-C_MDR and C-T-P_HDR was higher than those in T-W_LDR, T-T_LDR, and T-inP_MDR. Triticale in T-inP_MDR had higher grain protein content than both of the low diversity cereal rotations. The C-TP_HDR produced higher triticale biomass than T-W_LDR, T-T_LDR, and T-inP_MDR. Compared to continuous triticale, the C-T-P_HDR produced $14.2 \%$ more triticale grain yield and $13.9 \%$ more triticale biomass. Overall, the triticale grain yield responded to rotational diversity in the sequence of $\mathrm{HDR}>\mathrm{MDR}>\mathrm{LDR}$. There were no differences 
among rotational diversities for both broad leaf and grassy weed infestation (Table S3). The effects of cropping sequence on grassy weed biomass were relatively more variable among sites (data not shown).

Under high-yielding environments, the highest and lowest triticale grain yield were observed in C-T-P_HDR and T-T_LDR, respectively, which were $11.3 \%$ higher and 8.0\% lower, respectively, than the averaged triticale grain yield from all the six rotational schemes (Table S4). The same triticale grain yield ranking was observed under mediumyielding environments. Under low-yielding environments, all six rotational schemes displayed the same productivity. The T-C_MDR system produced the second highest triticale grain yield across all three production environments; whereas, the continuous triticale consistently displayed the lowest triticale grain yield in both medium- and highyielding environments.

Initially, triticale grain yield responses to diversity grouped tightly around $3 \mathrm{Mg} \mathrm{ha}^{-1}$. However, separation of responses occurred over time as a notable triticale grain yield increase was observed in C-T-P_HDR and T-C_MDR after 2 and 3 rotation cycles were completed, respectively (Table S1; Fig. S3). After completion of 3 rotational cycles, the triticale grain yield when sequenced with field pea appears to close the gap with triticale grain yield observed from the triticale-canola rotation. The results indicate that over the long-term the pea phase may become increasingly important and similar to the canola phase for triticale yield in a 2-yr rotational system. Trends for yield from low diversity rotations and the intercrop did not appear to change after 7 (continuous triticale) or 3 cycles of the 2-yr rotations. Moreover, continuous triticale grain yield displayed a slight reduction as the study progressed. The soil carbon and nitrogen displayed responses favorable to moderate and high diversity rotations (Table S5). When the study was completed at Lethbridge rainfed site, T-C_MDR, T-P_MDR and C-T-P_HDR accumulated higher soil carbon and nitrogen concentration than T-in P_MDR, T-W_LDR and T-T_ LDR. Both soil carbon and nitrogen concentration in T-W_LDR was the least. Soil microbial community was highly variable across rotations. For example, at Swift Current, C-TP_HDR and T-T_LDR displayed the highest and the lowest soil microbial community, respectively (Fig. S4). Also, the soil microbial community in C-T-P_HDR was 65\% higher than that in T-T_LDR.

\section{Cropping system stability}

The biplot of triticale grain yield responses and corresponding CV across all 22 site-years illustrated the superiority of a highly diverse rotation (C-T-P_HDR) for producing higher grain yield with lower variability (Group I) (Fig. S5). Continuous triticale (T-T_LDR) displayed the poorest in terms of low and highly variable grain yield. The triticale-canola rotation (T-C_MDR) produced above average triticale grain yield but did display greater than average system variability across sites. Removal of the canola phase from the system (i.e. only triticale-pea) caused a yield drag for triticale and greater system variability (Fig. S5). 


\section{Effects of rotational diversity on economic returns}

The net economic returns for rotational diversities were highly variable depending on the production environment. Under a high-yielding environment, all rotational diversity led to a net return in the order of C-T-P_HDR $\left(\$ 670 \mathrm{ha}^{-1}\right)>\mathrm{T}-\mathrm{C} \_\mathrm{MDR}\left(\$ 629 \mathrm{ha}^{-1}\right)>\mathrm{T}-\mathrm{P}$ $\operatorname{MDR}\left(\$ 531 \mathrm{ha}^{-1}\right)>\mathrm{T}-\mathrm{T} \operatorname{LDR}\left(\$ 465 \mathrm{ha}^{-1}\right)>\mathrm{T}-\mathrm{W} \operatorname{LDR}\left(\$ 458 \mathrm{ha}^{-1}\right)($ Table S6). The C-T$\mathrm{P} \_$HDR and T-C_MDR rotations provided net returns of $\$ 32$ and $\$ 48 \mathrm{ha}^{-1}$, respectively, under a medium-yielding environment. However, T-W_LDR provided a net loss of $\$ 123$ $\mathrm{ha}^{-1}$, and T-T_LDR and T-P_MDR had a net return of zero under the same production environment. All rotational schemes provided net losses ranging from \$201 to \$329 in a low-yielding environment (Table S6).

\section{Discussion}

Triticale produced superior grain yield and biomass when grown in highly diverse rotational systems, which underscores also the important contribution of canola and field pea to cereal-based cropping systems. Although not as apparent as the effect from inclusion of canola, the triticale responses to the integration of field pea indicate beneficial effect from pulses, which has been previously reported (Głąb et al. 2014). Pulse crops provide both nitrogen and non-nitrogen benefits, which include increased soil available nitrogen due to their ability to fix atmospheric $\mathrm{N}_{2}$ through symbiosis with Rhizobium (Peoples et al. 1995), improved soil structure and properties (Raimbault and Vyn 1991), and increased soil organic matter (Van Eerd et al. 2014). Over time, the positive contribution of field pea may become more apparent as T-P_MDR produced the second highest soil nitrogen concentration after 3 rotational cycles. Combined across all 22 site-years, T-P_MDR produced higher triticale yield than monoculture cereal systems (T-W_LDR and T-T_LDR). Our results confirmed that pulse crops in a rotational system provide benefits to the succeeding crop.

The importance of canola in triticale rotations was evident by the reduction in grain yield in triticale when the phase was absent. There are likely multiple biological explanations for the benefits that canola provided. One aspect explored by others (Smith et al. 2000) was that canola used less water than rainfall and resulted in a net storage of water in the soil profile, which will benefit the subsequent crop. This may explain why triticale sequenced with canola (C-T-P_HDR and T-C_MDR) yielded better than in the other rotations, particularly under rainfed conditions. Compared to C-T-P_HDR, T-P_MDR and T-inP_MDR produced $10.4 \%$ and $13.5 \%$ less yield for triticale, respectively (data not shown), which indicated that there was an apparent triticale yield drag when canola was removed from the rotational system. Therefore, adding a canola phase and extending the rotation cycle from two years to three years would improve triticale grain yield.

Many crops are hosts to arbuscular mycorrhizae fungi (AMF), which are microscopic organisms; however, canola is an exception (Ryan et al. 2002). Angus et al. (1991) reported that wheat planted after a non-AMF host like canola often yielded better than wheat after wheat. In addition, Rhizoctonia disease incidence is generally lower in wheat 
after canola (Cook 2012). Similar to the wheat example (Angus et al. 1991), triticale grain yield in our study was optimized following canola. Thus, the observations of triticale when sequenced with canola might in part be attributed to the interruption of triticale disease cycle or some other response caused by reduced AMF colonization in the system. Canola was also unique because it did not respond to increased diversity. For example, canola grain yields did not differ between 2 versus 3 -yr rotations $(\mathrm{P}=0.921$; data not shown), and explains why some producers successfully grow canola in very tight rotations over the short term given that rotations with high canola frequency can be more profitable over a short-term period (Harker et al. 2015). Nevertheless, pest (disease, insect and weed) management and soil health issues will arise with high canola frequency rotations over the long-term (Harker et al. 2015). Thus, diversity as a long-term strategy is also important for canola as Harker et al. (2015) reported a canola yield enhancement when rotational diversity increased because blackleg disease and root maggot damage were reduced. Similar to the tight canola rotations, the practice of continuous triticale has been employed when isolation of triticale or rye was needed, historically as a measure to prevent the spread of disease. However, isolation may also be desired in situations where, for example, pollen flow is a concern. Under this situation, a 14.0\% triticale grain yield penalty would occur from continuous monoculture compared to that observed in highly diverse rotations.

Higher soil microbial community and soil carbon concentration is likely associated with better soil health and fertility (Lupwayi et al. 1998). Although the net economic returns from rotational diversity involving field pea was not superior over rotations involving canola, the inclusion of field pea in the rotations had several other benefits that were not captured in our cost-benefit analyses. One of the most apparent benefits evaluated in the current study was the soil microbial community and soil carbon concentration improvement. Soil microbial community accumulation was superior in C-T-P_HDR, followed by T-P_MDR, and lowest in the T-T_LDR system. Soil carbon concentration in C-T-P_HDR, T-P_MDR and T-inP_MDR were higher than that in T-T_LDR (Table S5). It was notable that the field pea phase improved soil health and fertility but may only cause modest responses in yield and biomass of triticale. Limited field pea effects on triticale crop responses may be because of the difference in experimental environment. In our study, all but one location was conducted under a rainfed regime. Others (Debaeke and Hilaire 1997) observed that there was no rotational effect for both sunflower (Helianthus annuus L.) and winter wheat grown in a rapeseed (Brassica napus L.)-winter wheatsunflower-winter wheat rotational system under rainfed conditions. One report (Pakrou and Dillon 2000) indicated that the nitrogen fixed by irrigated white clover (Trifolium repens L.) was three times of that fixed by rainfed annual clover during a 12-month period. We believe that both the limited amount of nitrogen fixed by field pea and the weak nitrogen mineralization under rainfed environment caused less residual nitrogen to be available for the subsequent triticale in the 2 yr rotation.

Long-term monoculture systems have been frequently cited as causal to higher weed and disease infestations, which also reduces grain yield as compared systems with greater 
diversity (Andow 1983; Griffith et al. 1988). The use of synthetic chemicals for controlling diseases and weeds not only increases production costs, but can impose negative effects on the environment. Previous research reported that one of the most important rotational benefits was enhanced weed control (Blackshaw et al. 2001; Beres et al. 2010). Results from the current study indicated there was no difference among rotational diversity on weed population, which may be due to the relatively shorter duration of the experiment and low weed abundance and species distribution at the study sites.

Our previous research recommended displacing CPS entirely and replacing CWSWS in some regions with selected triticale varieties for feedstock utilization (Beres et al. 2013a). In the present study, the average triticale grain yield combined across all 22 siteyears was $3.64 \mathrm{Mg} \mathrm{ha}^{-1}$, which was nearly $22 \%$ greater than the $2.98 \mathrm{Mg} \mathrm{ha}^{-1}$ yield for the CWSWS wheat, while the total production costs were estimated to be the same $(\$ 652$ $\mathrm{ha}^{-1}$ ) in both crops (data not shown). Furthermore, the average price for triticale grain yield was $\$ 229 \mathrm{Mg}^{-1}$, which was $15 \%$ more than CWSWS wheat $\left(\$ 198 \mathrm{Mg}^{-1}\right)$. Given the same production cost concomitant with $22 \%$ greater yield and $15 \%$ price advantages for triticale over CWSWS wheat, producers would make more money by growing triticale than soft white spring wheat. Consistent triticale yield across diverse environments is one of the essential factors that influence net economic returns. Several researchers have reported that longer or more diverse rotations improved grain yield stability (Gaudin et al. 2015; Varvel 2000). The T-inP_MDR produced less variable, but lower triticale grain yield, which makes it less economically feasible for producers. The remaining four rotational treatments had either lesser grain yield potential or were less stable, which made them economically unsuitable for triticale producers. In the context of yield stability and net economic returns, C-T-P_HDR is the superior system in the study.

The responses of six levels of triticale-based rotational diversity, grouped into three categories of low, medium and high diversity, were explored. When grown in monoculture or in rotation with wheat, triticale displayed lower grain yield and biomass production than in a rotation with oilseed or pulses crops. Triticale grain yield in the 3-yr canolatriticale-field pea system was also more stable than the other rotations. Inclusion of a field pea phase improved soil health and led to greater yield stability of the triticale phase; other benefits to triticale yield were not as notable. Unlike triticale, canola grain yield did not respond to rotational diversity as grain yield in the 2 -yr rotation was similar to canola yield from the HDR system. The benefit of canola was notable as removing the canola phase from the system caused a yield drag in triticale. A $14 \%$ yield penalty will be experienced in a scenario where continuous triticale has to be grown in a confined area to prevent pollen escape or for disease isolation. Net economic returns were also superior for C-T-P_HDR $\left(\$ 670 \mathrm{ha}^{-1}\right)$ and the lowest for T-W_LDR $\left(\$ 458 \mathrm{ha}^{-1}\right)$. Overall, triticale responded positively to increased rotational diversity and displayed greater stability with the inclusion of field pea, leading to improved profitability and sustainability of the system. 


\section{Acknowledgements}

Funding for this project was provided by the Agriculture and Agri-Food Canada's Agricultural Bioproducts and Innovation Program (ABIP), SeCan, Canadian Triticale Bio refinery Initiative (www.ctbi.ca). Expert technical support provided by Ryan Beck, Ashley Brau, Sheree Daniels, Ryan Dyck, Janelle Hudak, Jordana Hudak, Jeff Michaelis, Regan Nielsen, Carol Sekura, Steven Simmill, Mary Williams, Dan Yagos, and Kim Ziegler.

\section{References}

Andow, D. 1983. The extent of monoculture and its effects on insect pest populations with particular reference to wheat and cotton. Agr. Ecosyst. Environ. 9:25-35.

Angus, J.F., Herwaarden, A.F.V., Howe, G.N. 1991. Productivity and break crop effects of winter-growing oilseeds. Aust. J. Exp. Agric. 31:669-677.

Anonymous. 2015. Crop planning guide 2015 Government of Saskatchewan, Regina, SK, p. 16.

Beres, B., Pozniak, C., Bressler, D., Gibreel, A., Eudes, F., Graf, R., Randhawa, H., Salmon, D., McLeod, G., Dion, Y., Irvine, B., Voldeng, H., Martin, R., Pageau, D., Comeau, A., DePauw, R., Phelps, S., Spaner, D., 2013a. A Canadian ethanol feedstock study to benchmark the relative performance of triticale: II. Grain quality and ethanol production. Agron. J. 105:1707-1720.

Beres, B., Pozniak, C., Eudes, F., Graf, R., Randhawa, H., Salmon, D., McLeod, G., Dion, Y., Irvine, B., Voldeng, H., Martin, R., Pageau, D., Comeau, A., DePauw, R., Phelps, S., Spaner, D. 2013b. A Canadian ethanol feedstock study to benchmark the relative performance of triticale: I. Agronomics. Agron. J. 105:1695-1706.

Beres, B.L., Harker, K.N., Clayton, G.W., Blackshaw, R.E., Graf, R.J. 2010. Weed competitive ability of spring and winter cereals in the Northern Great Plains. Weed Technol. 24:108-116.

Blackshaw, R.E., Larney, F.J., Lindwall, C.W., Watson, P.R., Derksen, D.A. 2001. Tillage intensity and crop rotation affect weed community dynamics in a winter wheat cropping system. Can. J. Plant Sci. 81:805813.

Cook, A., Wilhelm, N. Vvsr, G. Frischke, A. 2012. The impact of crop rotation and nutrition on Rhizoctonia disease incidence in cereals on grey calcareous soils of upper Eyre Peninsula, in: Yunusa., I. (ed.), Capturing Opportunities and Overcoming Obstacles in Australian Agronomy. Proceedings of $16^{\text {th }}$ Australian Agronomy Conference. Armidale, NSW, pp. 14-18.

Cutforth, H.W., Angadi, S.V., McConkey, B.G., Miller, P.R., Ulrich, D., Gulden, R., Volkmar, K.M., Entz, M.H., Brandt, S.A. 2013. Comparing rooting characteristics and soil water withdrawal patterns of wheat with alternative oilseed and pulse crops grown in the semiarid Canadian prairie. Can. J. Soil Sci. 93:147160 .

Davis, A.S., Hill, J.D., Chase, C.A., Johanns, A.M., Liebman, M. 2012. Increasing cropping system diversity balances productivity, profitability and environmental health. PLoS ONE 7, e47149.

Debaeke, P., Hilaire, A. 1997. Production of rainfed and irrigated crops under different crop rotations and input levels in southwestern France. Can. J. Plant Sci. 77:539-548.

Doran, J.W. 2002. Soil health and global sustainability: translating science into practice. Agric. Ecosyst. Environ. 88:119-127.

Francis, T.R., Kannenberg, L.W. 1978. Yield stability studies in short-season maize. I. A descriptive method for grouping genotypes. Can. J. Plant Sci. 58:1029-1034.

Gan, Y., Hamel, C., O’Donovan, J.T., Cutforth, H., Zentner, R.P., Campbell, C.A., Niu, Y., Poppy, L. 2015. Diversifying crop rotations with pulses enhances system productivity. Sci. Rep. 5:14625.

Gaudin, A.C.M., Tolhurst, T.N., Ker, A.P., Janovicek, K., Tortora, C., Martin, R.C., Deen, W. 2015. Increasing crop diversity mitigates weather variations and improves yield stability. PLoS ONE 10, e0113261.

Głąb, T., Ścigalska, B., Łabuz, B. 2014. Effect of crop rotation on the root system morphology and productivity of triticale ( $\times$ Triticosecale Wittm). J. Agric. Sci. 152:642-654. 
Griffith, D.R., West, T.D., Parsons, S.D., Kladivko, E.J., Mannering, J.V. 1988. Long-term tillage and rotation effects on corn growth and yield on high and low organic matter, poorly drained soils. Agron. J. 80:599605.

Harker, K.N., O’Donovan, J.T., Turkington, T.K., Blackshaw, R.E., Lupwayi, N.Z., Smith, E.G., Johnson, E.N., Gan, Y., Kutcher, H.R., Dosdall, L.M., Peng, G. 2015. Canola rotation frequency impacts canola yield and associated pest species. Can. J. Plant Sci. 95:9-20.

Irvine, R.B., Lafond, G.P., May, W., Kutcher, H.R., Clayton, G.W., Harker, K.N., Turkington, T.K., Beres, B.L. 2013. Stubble options for winter wheat in the black soil zone of western Canada. Can. J. Plant Sci. 93:261270.

Karp, A., Richter, G.M. 2011. Meeting the challenge of food and energy security. J. Exp. Bot. 62:3263-3271.

Kirschenmann, F. 2002. Why American agriculture is not sustainable. Renewable Resour. J. 20:7-11.

Littell, R.C., Milliken, G.A., Stroup, W.W., Wolfinger, R.D. 2006. SAS® system for mixed models. SAS Institute Inc., New York.

Lupwayi, N.Z., Rice, W.A., Clayton, G.W. 1998. Soil microbial diversity and community structure under wheat as influenced by tillage and crop rotation. Soil Biol. Biochem. 30:1733-1741.

McLeod, J.G., Pfeiffer, W.H., DePauw, R.M., Clarke, J.M. 2001. Registration of AC Ultima spring triticale. Crop Sci. 41:924-925.

Pakrou, N., Dillon, P. 2000. Key processes of the nitrogen cycle in an irrigated and a non-irrigated grazed pasture. Plant Soil 224:231-250.

Peoples, M.B., Herridge, D.F., Ladha, J.K. 1995. Biological nitrogen fixation: An efficient source of nitrogen for sustainable agricultural production? Plant Soil 174:3-28.

Raimbault, B.A., Vyn, T.J. 1991. Crop rotation and tillage effects on corn growth and soil structural stability. Agron. J. 83:979-985.

Randhawa, H.S., Sadasivaiah, R.S., Graf, R.J., Beres, B.L. 2012. Bhishaj soft white spring wheat. Can. J. Plant Sci. 91:805-810.

Ryan, M.H., Norton, R.M., Kirkegaard, J.A., McCormick, K.M., Knights, S.E., Angus, J.F. 2002. Increasing mycorrhizal colonisation does not improve growth and nutrition of wheat on Vertosols in south-eastern Australia. Aust. J. Agric. Res. 53:1173-1181.

Smith, C., Bond, W., Verburg, K., Dunin, F. 2000. Water use of cereal-canola-lucerne rotations in southeastern Australia, nuclear techniques in integrated plant nutrient, water and soil management. International Atomic Energy Agency, Vienna, Austria, pp. 178-184.

Sumner, D.R., Doupnik, B., Boosalis, M.G. 1981. Effects of reduced tillage and multiple cropping on plant diseases. Annu. Rev. Phytopathol. 19:67-187.

Van Eerd, L.L., Katelyn, A.C., Adam, H., Anne, V., David, C.H. 2014. Long-term tillage and crop rotation effects on soil quality, organic carbon, and total nitrogen. Can. J. Plant Sci. 94:303-315.

Varvel, G.E. 2000. Crop rotation and nitrogen effects on normalized grain yields in a long-term study. Agron. J. 92:938-941.

Warkentin, T., Vandenberg, A., Banniza, S., Slinkard, A. 2004. CDC Golden field pea. Can. J. Plant Sci. 84:237-238.

Warkentin, T., Vandenberg, A., Tar'an, B., Barlow, S., Ife, S. 2007. CDC Meadow field pea. Can. J. Plant Sci. 87:909-910.

Williams, C.M., King, J.R., Ross, S.M., Olson, M.A., Hoy, C.F., Lopetinsky, K.J. 2014. Effects of three pulse crops on subsequent barley, canola, and wheat. Agron. J. 106:343-350.

\section{Electronic Supplementary Material (ESM)}

Electronic Supplementary Material (ESM) associated with this article can be found at the website of CRC at https://akademiai.com/loi/0806

Electronic Supplementary Table S1. Summary of six triticale-based rotational schemes from 2008 to 2014 
Electronic Supplementary Table S2. Yield $\left(\mathrm{Mg} \mathrm{ha}^{-1}\right)$ summary for the four major crop phases measured across 22 site-years

Electronic Supplementary Table S3. Response of triticale to six rotational schemes averaged over all site-years.

Electronic Supplementary Table S4. Influence of production environment on triticale yield $\left(\mathrm{Mg} \mathrm{ha}^{-1}\right)$

Electronic Supplementary Table S5. Soil carbon and nitrogen responses from six triticale-based rainfed rotations measured from the $0-15 \mathrm{~cm}$ soil depth at Lethbridge, Alberta, Canada

Electronic Supplementary Table S6. Summary of economic returns for five triticale-based rotational schemes evaluated from 2008 to 2014 across 22 site-years in western Canada

Electronic Supplementary Figure S1. Monthly accumulated precipitation and mean temperature at Lethbridge, $\mathrm{AB}$, Swift Current, SK, and Canora, SK during the experimental period

Electronic Supplementary Figure S2. Annual average grain yield of the four crops at four locations. The data in 2008, 2009 and 2011 were averaged from all sites, in 2010 and 2012 from Lethbridge irrigated, Lethbridge rainfed and Swift Current, and in 2013 and 2014, from Lethbridge irrigated and Lethbridge rainfed

Electronic Supplementary Figure S3. Triticale grain yield trends from the $2^{\text {nd }}$ to the $7^{\text {th }}$ year after study initiation for the six triticale-based rotations. The data in the $2^{\text {nd }}$ year were averaged from all sites, in the $4^{\text {th }}$ year were from Lethbridge irrigated, Lethbridge rainfed and Swift Current, and in the $7^{\text {th }}$ year were from Lethbridge irrigated and Lethbridge rainfed. C-T-P_HDR, T-W_LDR, T-C_MDR, T-inP_MDR, T-P_MDR and T-T_LDR represent canola-triticale-field pea high diversity rotation, triticale-wheat low diversity rotation, triticale-canola medium diversity rotation, triticale-two field pea intercrop medium diversity rotation, triticale-field pea medium diversity rotation, and triticale-triticale low diversity rotation, respectively

Electronic Supplementary Figure S4. Effect of triticale-based rotations on soil microbial biomass C (MBC). The data used were from Swift Current site collected in 2012. C-T-P_HDR, T-P_MDR, T-W_LDR, T-in P_ MDR, T-C MDR and T-T LDR represent canola-triticale-field pea high diversity rotation, triticale-field pea medium diversity rotation, triticale-wheat low diversity rotation, triticale-two field pea intercrop medium diversity rotation, triticale-canola medium diversity rotation and triticale-triticale low diversity rotation, respectively

Electronic Supplementary Figure S5. Triticale grain yield responses to rotational diversity. The four groups are characterized by high mean grain yield and low CV (optimal as in Group I); high mean grain yield and high $\mathrm{CV}$ (Group II); low mean grain yield and high CV (poor, as in Group III); and low mean grain yield and low CV (Group IV).C-T-P_HDR, T-C_MDR, T-P_MDR, T-T_LDR, T-W_LDR and T-inP_MD represent canolatriticale-field pea high diversity rotation, triticale-canola medium diversity rotation, triticale-field pea medium diversity rotation, triticale-triticale low diversity rotation, triticale-wheat low diversity rotation and triticale-two field pea intercrop medium diversity rotation, respectively 